\title{
Atrial natriuretic peptide reduces the $\alpha$-subunit of the epithelial sodium channel mRNA expression in the mouse stria vascularis
}

\author{
YAN LUO $^{1}$, QINGJIE XIA ${ }^{2}$, ZENGLIANG XIA $^{2}$ and YUEDI TANG ${ }^{1}$ \\ ${ }^{1}$ Department of Otorhinolaryngology and Translational Neuroscience Center, West China Hospital of Sichuan University; \\ ${ }^{2}$ West China Laboratory of Molecular Genetics, Sichuan University, Chengdu, Sichuan 610041, P.R. China
}

Received November 12, 2014; Accepted November 19, 2014

DOI: $10.3892 /$ br. 2014.400

\begin{abstract}
Atrial natriuretic peptide (ANP) is extensively expressed in the cochlea, including the strial vascularis $(\mathrm{StV})$. ANP may participate in the regulation of the water-electrolyte balance. However, the functional significance of ANP in the cochlea is less understood and little is known regarding the exact mechanisms. Studies suggest that the epithelial sodium channel $(\mathrm{ENaC})$ is important for regulating sodium transport across epithelia. $\mathrm{ENaC}$ may be involved in the clearance of endolymphatic $\mathrm{Na}^{+}$and maintenance of a K-rich and Na-poor composition in the endolymph. Whether ANP has a regulatory effect on the $\mathrm{Na}^{+}$channel in the $\mathrm{StV}$ remains unknown. The aim of the present study was to evaluate whether ANP affects the expression of the $\alpha$-subunit of the ENaC $(\alpha-E N a C)$ mRNA in the mouse $\mathrm{StV}$, using the reverse transcription-quantitative polymerase chain reaction (RT-qPCR) technique. The mouse StV tissues were incubated with $10^{-6} \mathrm{~mol} / 1$ ANP for different times $(2,6,12,24$ and $48 \mathrm{~h}$ ) and were subsequently harvested. $\alpha$-ENaC mRNA was extracted for RT-qPCR analysis of the expression. The study demonstrated the existence of $\alpha-E N a C$ in the mouse $\mathrm{StV}$. Tissues treated with ANP $\left(10^{-6} \mathrm{~mol} / \mathrm{l}\right)$ showed a significant reduction in $\alpha-E N a C$ mRNA expression $(\mathrm{n}=3, \mathrm{P}<0.05)$. A maximum effect was reached at $2 \mathrm{~h}$ after treatment. The present results indicate that ANP may regulate cochlear ion
\end{abstract}

Correspondence to: Dr Yuedi Tang, Department of Otorhinolaryngology and Translational Neuroscience Center, West China Hospital of Sichuan University, 37 Guo-Xue-Xiang Road, Chengdu, Sichuan 610041, P.R. China

E-mail: tangyd@hotmail.com

Abbreviations: ANP, atrial natriuretic peptide; ENaC, epithelial sodium channel; $\alpha$-ENaC, $\alpha$-subunit of the epithelial sodium channel; $\mathrm{StV}$, strial vascularies; RT-PCR, reverse transcription-polymerase chain reaction; $A C T B, \beta$-actin

Key words: atrial natriuretic peptide, $\alpha$-subunit of the epithelial sodium channel, strial vascularis, reverse transcription-quantitative polymerase chain reaction transport and endolymph fluid balance in the inner ear via reducing expression of the $\alpha-E N a C$ mRNA in the mouse $\mathrm{StV}$.

\section{Introduction}

Atrial natriuretic peptide (ANP), which was first extracted from rat atrial tissue by Baines et al, is now known to be a member of the natriuretic peptide family (1). The natriuretic peptide family consists of a family of 5 natriuretic peptides that include A-, B-, C-type natriuretic peptide, urodilatin and Dendroaspis natriuretic peptide (2). The pathophysiological actions of various natriuretic peptides are mediated by three different natriuretic peptide receptors; atrial natriuretic peptide receptor-A-type (NPR-A), NPR-B- and NPR-C (3). ANP, an A-type natriuretic peptide, has been reported to have a wide variety of biological functions, not only in the circulatory system but also in the kidney and other tissues (3). ANP acts to reduce the water, sodium and adipose loads on the circulatory system, thereby reducing blood pressure.

ANP receptors are distributed extensively in the cochlea, including the strial vascularis (StV). Lamprecht and Meyer zum Gottesberge (4) first reported that ANP receptors are expressed in the inner ear of guinea pigs. Previous studies have also identified ANP receptors in the inner ear of guinea pigs and rats, and demonstrated their presence in the $\mathrm{StV}$, spiral ligament in the cochlea and the secretory epithelium of the vestibular organ (4-10).

Studies suggest that ANP may be locally synthesized and activates NPR-A in a paracrine/autocrine manner (4-8). Pronounced immunoreactivity for ANP was observed in the spiral ligament of the cochlear lateral wall. ANP has been demonstrated to be expressed mainly in the cytoplasm of the $\mathrm{StV}$ marginal cells of normal guinea pigs (11).

Epithelial sodium channel $(\mathrm{ENaC})$ consists of three different subunits: $\alpha, \beta$ and $\gamma$, with the $\alpha$-subunit $(\alpha-\mathrm{ENaC})$ being the most critical for channel functionality (12). Studies suggest that $\mathrm{ENaC}$ is important for regulating sodium transport across epithelia. ENaC has been shown to participate in transepithelial $\mathrm{Na}^{+}$transport in epithelia of various organs, such as kidney, colon, lung, sweat glands and salivary glands (13). $\mathrm{ENaC}$ is located in the apical membrane of epithelia facing the endolymph, $\mathrm{StV}$, spiral prominence and spiral limbus in the inner ear. The endolymph in the cochlea is characterized by a high $\mathrm{K}^{+}$concentration of $\sim 150 \mathrm{mM}$ and low $\mathrm{Na}^{+}$concentration 
of $\sim 1 \mathrm{mM}$. ENaC may be involved in transepithelial $\mathrm{Na}^{+}$ transport through the apical membrane and maintenance of a K-rich and Na-poor composition in the endolymph (14).

ANP may participate in the regulation of the water-electrolyte balance (15). However, little is known regarding the exact mechanisms of ANP in the regulation of the water-electrolyte balance in the cochlea. Whether ANP has a regulatory effect on the $\mathrm{ENaC}$ in the $\mathrm{StV}$ remains unknown. Reverse transcription-quantitative polymerase chain reaction (RT-qPCR) is a highly sensitive technology that allows high throughput quantification of gene expression (16). In the present study, RT-qPCR was used to evaluate whether ANP affects $\alpha-E N a C$ mRNA expression in the mouse StV.

\section{Materials and methods}

Animals. Healthy adult Kunming mice were provided by the Animal Care and Use committee at the Huaxi Medical School of Sichuan University. The study was approved by the Animal Care and Use Committee at the West China Medical School of Sichuan University (Sichuan, China). The temporal bone was removed and $\mathrm{StV}$ tissues were dissected at $4^{\circ} \mathrm{C}$, as previously described (17).

Tissues culture. StV tissues were dissected and rinsed in saline solution prior to being placed in culture plates. All the experimental specimens were cultured in Dulbecco's modified Eagle's medium/nutrient mixture F-12 (1:1) containing 10\% fetal bovine serum, $50 \mathrm{mM}$ glucose, $100 \mathrm{U} / \mathrm{ml}$ penicillin and $2 \mu \mathrm{l} / \mathrm{ml}$ insulin-transferrin selenium sodium mixture. StV tissues were co-cultured with ANP $\left(10^{-6} \mathrm{~mol} / \mathrm{l}\right)$ in a standard cell culture incubator at $37^{\circ} \mathrm{C}, 5 \% \mathrm{CO}_{2}$ and $80 \%$ humidity for different times $(2,4,6,12,24$ and $48 \mathrm{~h})$.

RNA isolation and reverse transcription. Total RNA from the tissues of the cultured $\mathrm{StV}$ in the mouse cochlea was isolated using the TRIzol reagent (MRC, Cincinnati, OH, USA). RNA was reverse transcribed into cDNA using the RevertAid ${ }^{\mathrm{TM}}$ First Strand cDNA Synthesis kit (MBI Fermentas, Inc., Burlington, ON, Canada) with the addition of random hexamer primers. Briefly, $5 \mu \mathrm{l}$ purified RNA was used as template for cDNA synthesis in the presence of $1 \mu 1$ Moloney murine leukemia virus reverse transcriptase (200 units), $1 \mu 1$ random hexamer primer, $4 \mu 15 \mathrm{X}$ reaction buffer, $2 \mu 1$ hexamer 1X (Roche, Indianapolis, IN, USA), $2 \mu 1$ dNTP mix (10 mM each) and $6 \mu 1$ RNase-free water. After incubation for $60 \mathrm{~min}$ at $42^{\circ} \mathrm{C}$, the reverse transcriptase was inactivated at $70^{\circ} \mathrm{C}$ for $10 \mathrm{~min}$ and the cDNAs were stored at $-20^{\circ} \mathrm{C}$ until further analysis.

Primers. SCNNIA is a gene encoding the $\alpha-\mathrm{ENaC}$ protein. Primers were designed according to the NCBI GenBank sequences of mice and were synthesized by the Sangon Biotech (Shanghai, China). The primer sequences for RT-qPCR are as follows. Outer primers: SCNNIA forward, CACAGCAGGTGT GCATT and reverse, CAGCCTGCAGTTTATAGT. Inner primers for the second-round PCR reaction: SCNNIA forward, CATTCACTCCTGCTTCCAG and reverse, GTAGCAGTA GCCCCAGGAG; ACTB forward, GAAGATCAAGATCAT TGCTCCT and reverse, TACTCCTGCTTGCTGATCCA.
First-round PCR reaction. The reaction mixture for the first-round PCR contains $3 \mu \mathrm{l}$ 10X PCR buffer, $1.8 \mu \mathrm{l} 25 \mathrm{mM}$ $\mathrm{MgCl}_{2}, 11 \mu \mathrm{mol}$ each primer (SCNNIA forward and reverse) (Qiagen-Operon, Cologne, Germany), $0.36 \mu l$ deoxynucleoside triphosphate mix, $0.3 \mu 1$ Taq DNA polymerase, $5 \mu 1$ DNA template and water to a final volume of $30 \mu \mathrm{l}$. The first-round amplification was carried out in a thermocycler under the following conditions: 45 cycles at $94^{\circ} \mathrm{C}$ for $2 \mathrm{~min}, 94^{\circ} \mathrm{C}$ for $20 \mathrm{sec}$ and $54^{\circ} \mathrm{C}$ for $30 \mathrm{sec}$, with a final extension at $70^{\circ} \mathrm{C}$ for $40 \mathrm{sec}$ and at $70^{\circ} \mathrm{C}$ for $5 \min 4^{\circ} \mathrm{C}$.

Second-round PCR reaction. $\mathrm{qPCR}$ was used to determine the gene expression profiles of $\alpha-E N a C$. cDNA was amplified by RT-qPCR using an FTC-2000 (Funglyn, Toronto, ON, Canada). Each analysis was performed in a total volume of $30 \mu \mathrm{l}$ reaction mixture containing $5 \mu \mathrm{l}$ cDNA sample, $1 \mu \mathrm{l}$ SYBR-Green I and $2 \mu \mathrm{l}$ gene-specific forward and reverse primers (10 $\mu \mathrm{M}$ each). Reference genes were included to normalize the data. Amplifications were performed as follows: 45 cycles at $94^{\circ} \mathrm{C}$ for $2 \mathrm{~min}, 94^{\circ} \mathrm{C}$ for $20 \mathrm{sec}$ and $54^{\circ} \mathrm{C}$ for $20 \mathrm{sec}$, with a final extension at $70^{\circ} \mathrm{C}$ for $30 \mathrm{sec}$ and at $80^{\circ} \mathrm{C}$ for $20 \mathrm{sec}$.

The cycle threshold $(\mathrm{Ct})$ number, defined as the number of PCR amplification cycles required to reach fluorescent intensity above the threshold, was determined for each gene and each developmental time point was analyzed. Using serial dilutions of the test sample cDNA, the standard curve was generated on the basis of the linear relationship of existing $\mathrm{Ct}$ and the logarithm of the copy number. The SCNNIA slope of the standard curve was shown to be -3.32 and a strong linear association was demonstrated $\left(\mathrm{R}^{2}=1.00\right.$; Fig. 1A). The $A C T B$ standard slope of the curve was also shown to be -3.32 and a strong linear association was demonstrated $\left(\mathrm{R}^{2}=1.00\right.$; Fig. $\left.1 \mathrm{~B}\right)$.

Analysis. Samples were normalized internally using the $\mathrm{Ct}$ number of the reference gene $A C T B$ as follows: $\triangle \mathrm{Ct}$ $($ sample $)=\mathrm{Ct}$ (sample) $-\mathrm{Ct}(A C T B)$. The mean Ct of $\alpha-E N a C$ in $0 \mathrm{~h}$ (control) was set to a relative quantity (RQ) value of 1 using the $\Delta \Delta \mathrm{Ct}$, calculated as follows: $\Delta \Delta \mathrm{Ct}$ (sample) $=\Delta \mathrm{Ct}$ (sample) - $\Delta \mathrm{Ct}$ (control) and $\mathrm{RQ}=2^{-\Delta \Delta \mathrm{Ct}}$. The data is presented as mean \pm standard deviation. The one-way analysis of variance was performed using SPSS 11.0 statistical software (SPSS, Inc., Chicago, IL, USA). $\mathrm{P}<0.05$ was considered to indicate a statistically significant difference.

\section{Results}

Using RT-qPCR, $\alpha-E N a C$ mRNA was demonstrated to be expressed in the $\mathrm{StV}$ (Fig. 2). ACTB was examined as a reference gene. $\alpha-E N a C$ cDNA amplified from homogenates of the amplified fragments were of the expected sizes [124 basepairs (bp) for the $\alpha-E N a C$ gene (Fig. 2A) and $111 \mathrm{bp}$ for the reference, $A C T B$ cDNA (Fig. 2B)]. Tissues treated with ANP $\left(10^{-6} \mathrm{~mol} / \mathrm{l}\right)$ for different times $(2,6,12,24$ and $48 \mathrm{~h})$ showed that ANP decreased $\alpha-E N a C$ mRNA expression, and at the time of $2 \mathrm{~h}$ a maximum effect was reached $(\mathrm{n}=3, \mathrm{P}<0.05)$ (Fig. 3). This effect was slightly reversed after $6 \mathrm{~h}$. When $\alpha$-ENaC mRNA level was evaluated chronologically in a series of cultured explants, a stability along with culture time was noticed, after 12, 24 and 48 h respectively (Fig. 3). 
A
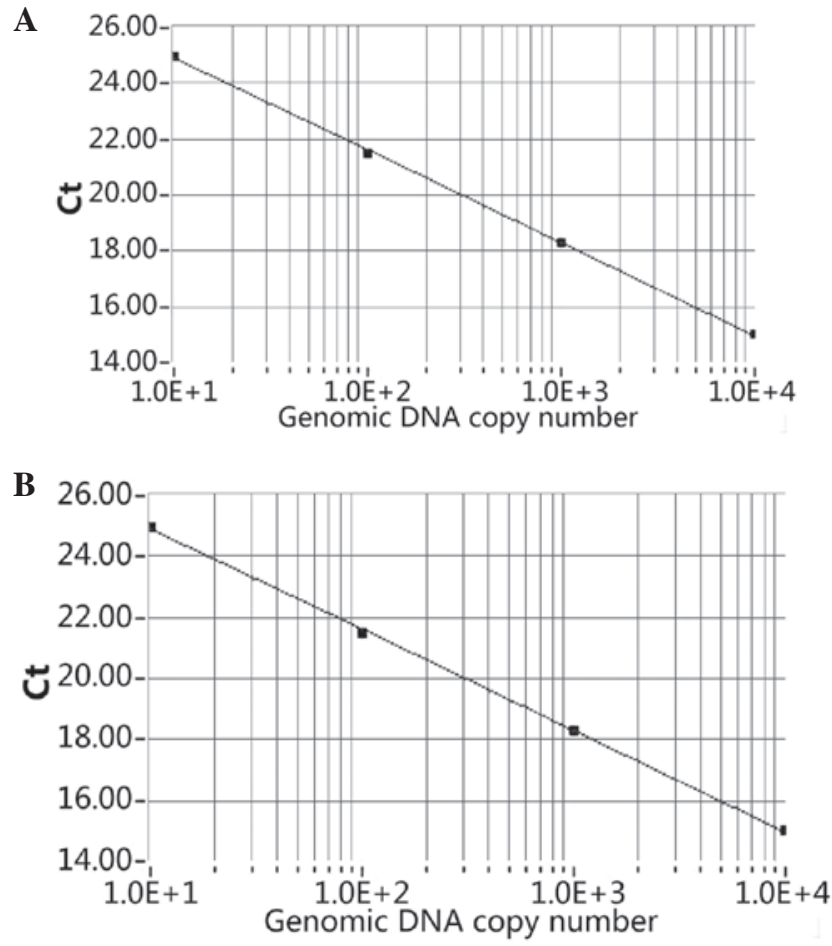

Figure 1. Standard curves for the (A) SCNN1A and (B) ACTB set generated from cycle threshold $(\mathrm{Ct})$ values and plotted against the input standard genomic DNA molecules.

\section{Discussion}

The $\mathrm{StV}$ is mainly responsible for generating the high $\mathrm{K}^{+}$and low $\mathrm{Na}^{+}$levels in the endolymph, which plays an important role in normal auditory function (17). The $\mathrm{StV}$ is bound by several types of parasensory epithelium. Previously is has been suggested that several different ion channels are present in these parasensory epithelium cells, which include the IsK/KvLQT1, $\mathrm{Ca}^{2+}$-activated nonselective cation, $\mathrm{Cl}^{-}$and $\mathrm{ENaC}$ channels $(12,18)$. The IsK/KvLQT1 channel has been shown to be the main pathway across the apical membrane of strial marginal cells for secreting $\mathrm{K}^{+}$into the lumen of the inner ear. $\mathrm{ENaC}$ has been shown to participate in reabsorbing $\mathrm{Na}^{+}$in the apical membrane of epithelia, which is located in the apical membrane of epithelia facing endolymph.

$\mathrm{ENaC}$ is critical in maintaining the sodium balance and water-electrolyte balance. Together with basolateral $\mathrm{Na}^{+} / \mathrm{K}^{+}$-ATPase, $\mathrm{ENaC}$ regulates sodium reabsorption and plays a major role in the control of total body salt and water homeostasis (12). In numerous types of cells, it has been shown that $\mathrm{ENaC}$ is regulated by a variety of extrinsic factors, such as proteolytic cleavage, mechanical and cytoskeletal activity. $\mathrm{ENaC}$ has also been shown to be under the control of different hormones, such as aldosterone, arginine vasopressin, endothelin, insulin and ANP (19).

We have previously shown the presence of NPR-A transcripts in the mouse $\mathrm{StV}$, as well as in the nonstrial tissue of the cochlear lateral wall and vestibular organ by PCR $(9,10)$. Gene expression of NPR-A in the StV was higher compared to the nonstrial and vestibula $(9,10)$. In the present study, the effect of ANP on the expression of the $\alpha-E N a C$ mRNA was investigated in the mouse StV by the RT-qPCR technique.
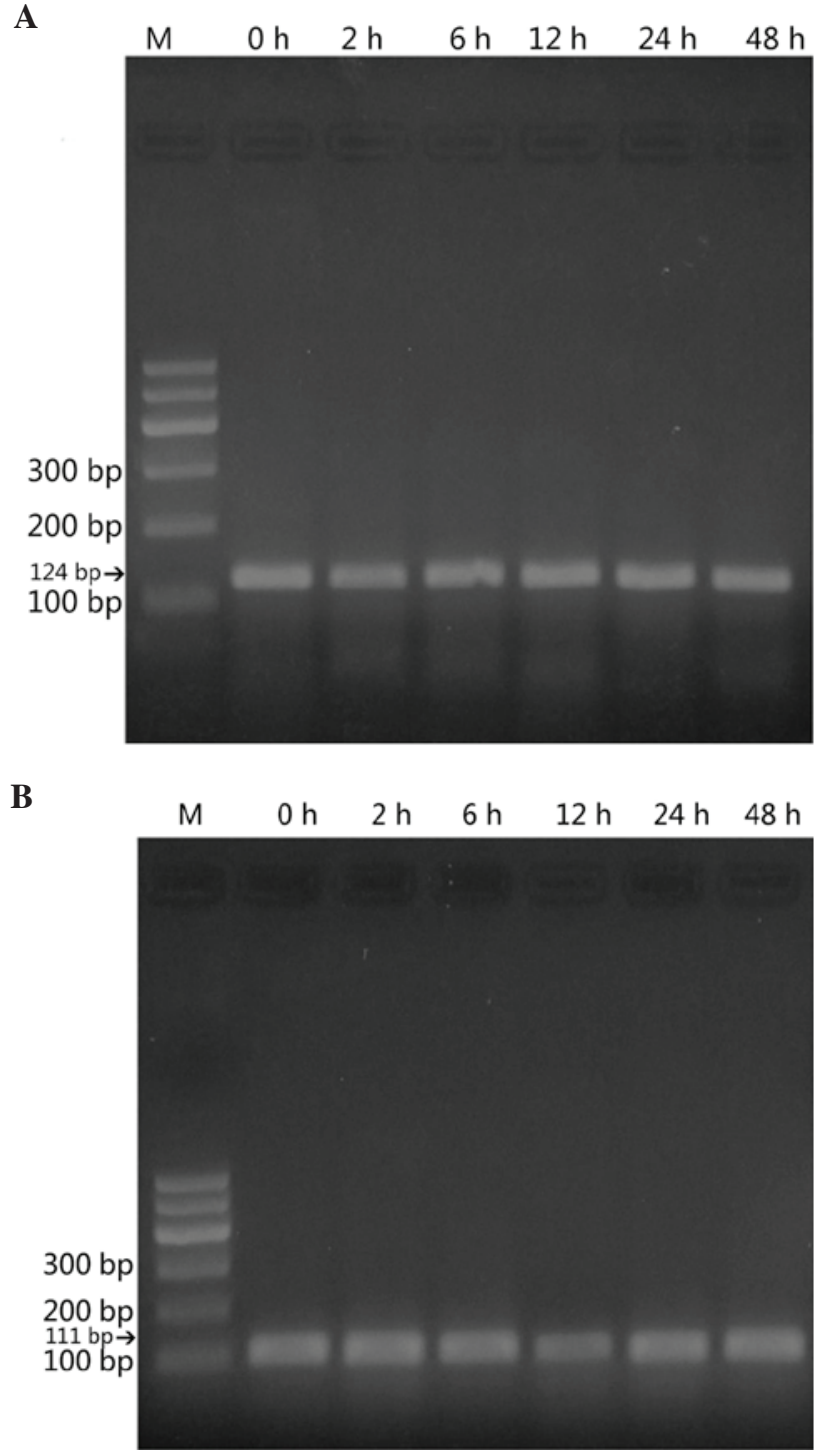

Figure 2. (A) $\alpha$-subunit of the epithelial sodium channel ( $\alpha-E N a C$ ) cDNA amplified from the strial marginal cells. The amplified fragments were of the expected sizes of $124 \mathrm{bp}$ for the $\alpha-E N a C$ gene. (B) The amplification of a $111 \mathrm{bp}$ fragment of $A C T B$ cDNA as a reference control is also shown.

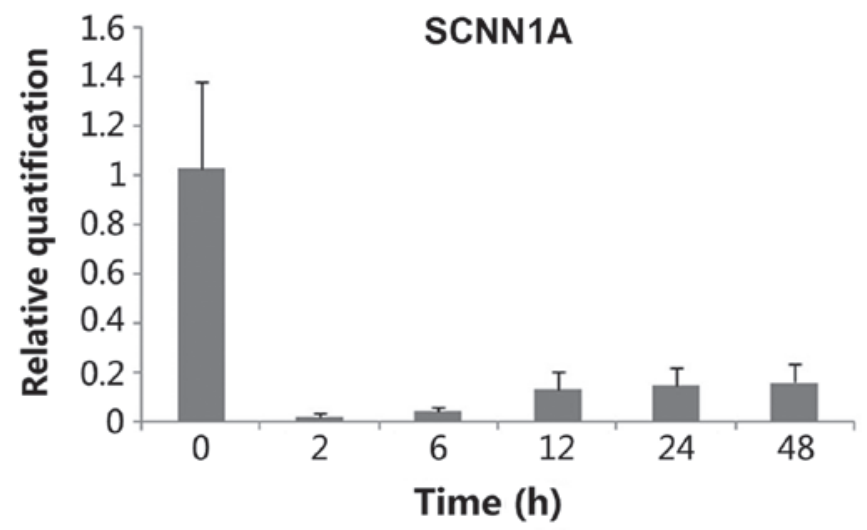

Figure 3. mRNA expression of $\alpha$-subunit of the epithelial sodium channel $(\alpha-E N a C)$ by reverse transcription-quantitative polymerase chain reaction. $\alpha-E N a C$ mRNA expression was normalized to the expression of $\alpha-E N a C$ in $0 \mathrm{~h}$ (control), which was arbitrarily set to a value of 1 . $\mathrm{P}<0.05$ is considered to indicate a significantly different expression and data are expressed as the average \pm standard deviation 
The study showed that ANP significantly decreases $\alpha-E N a C$ mRNA expression in the mouse $\mathrm{StV}$ and at the time of $2 \mathrm{~h}$ a maximum effect was reached. ANP may exert its inhibitory activity on $\mathrm{Na}^{+}$reabsorption through suppression of $E N a C$ gene expression in the mouse $\mathrm{StV}$.

The inhibitory effect by ANP on the $\alpha-E N a C$ mRNA may reduce the clearance of $\mathrm{Na}^{+}$. Inhibition of $\mathrm{ENaC}$ is expected to lead to an increase in endolymphatic $\mathrm{Na}^{+}$concentration, subsequently resulting in an elevation in endolymph volume. An increase of the endolymph volume may aggravate the endolymphatic hydrops. ANP is believed to influence the ionic homeostasis of the endolymph by regulating the $\mathrm{ENaC}$ in $\mathrm{StV}$. This effect may be more evident in pathological conditions, such as severe congestive heart failure when endogenous ANP is significantly increased.

The precise mechanisms of ANP in strial marginal cells remain unclear. ANP was shown to mediate the majority of its biological functions through interaction with NPR-A via cyclic guanosine monophosphate (cGMP), a second messenger (20). ANP is a classical inhibitor of $\mathrm{Na}^{+}$reabsorption induced by aldosterone at renal distal tubule and collecting duct segments, possibly via cGMP and protein kinase $\mathrm{G}$ intracellular second messengers (21-23). Previously, it has been shown that cGMP is involved in the control of gene expression via its action on different gene-promoter regions or by controlling the activities of transcription factors $(24,25)$.

The finding of the present study that $\alpha-E N a C$ is expressed in the $\mathrm{StV}$ supports a functional role for $E N a C$ in the regulation of $\mathrm{Na}^{+}$concentration. Although the pathophysiological significance of the inhibition of the $\alpha-E N a C$ mRNA expression by ANP in the mouse $\mathrm{StV}$ remains unknown in the present study, it may take part in the modulation of homeostasis of the endolymph. Further investigation is required to explore the detailed molecular and cellular mechanisms by which ANP modulates the expression of the $\alpha-E N a C$ mRNA in the mouse $\mathrm{StV}$.

In conclusion, to the best of our knowledge, the present study is the first to directly access the effect of ANP on $\alpha$-ENaC mRNA expression in the mouse StV. These results indicate that ANP has a physiological importance in the regulation of ion transport and endolymph fluid balance in the inner ear.

\section{Acknowledgements}

The authors would like to thank Ms Yanfang Chen for her technical assistance. The present study was supported by the National Natural Science Foundation of China (grant no. NSFC 81271079 to Dr Yuedi Tang).

\section{References}

1. Baines AD, DeBold AJ and Sonnenberg H: Natriuretic effect of atrial extract on isolated perfused rat kidney. Can J Physiol Pharmacol 61: 1462-1466, 1983.
2. Cea LB: Natriuretic peptide family: new aspects. Curr Med Chem Cardiovasc Hematol Agents 3: 87-98, 2005.

3. Brenner BM, Ballermann BJ, Gunning ME and Zeidel ML: Diverse biological actions of atrial natriuretic peptide. Physiol Rev 70: 665-699, 1990.

4. Lamprecht J and Meyer zum Gottesberge AM: The presence and localization of receptors for atrial natriuretic peptide in the inner ear of the guinea pig. Arch Otorhinolaryngol 245: 300-301, 1988.

5. Koch T, Gloddek B and Gutzke S: Binding sites of atrial natriuretic peptide (ANP) in the mammalian cochlea and stimulation of cyclic GMP synthesis. Hear Res 63: 197-202, 1992.

6. Seebacher T, Beitz E, Kumagami H, Wild K, Ruppersberg JP and Schultz JE: Expression of membrane-bound and cytosolic guanylyl cyclases in the rat inner ear. Hear Res 127: 95-102, 1999.

7. Meyer zum Gottesberge A, Schleicher A, Drummer C and Gerzer R: The volume protective natriuretic peptide system in the inner ear. Comparison between vestibular and cochlear compartments. Acta Otolaryngol Suppl 520: 170-173, 1995.

8. Meyer zum Gottesberge A and Lamprecht J: Localization of the atrial natriuretic peptide binding sites in the inner ear tissue - possibly an additional regulating system. Acta Otolaryngol Suppl 468: 53-57, 1989.

9. Long L, Tang Y, Xia Q, Xia Z and Liu J: Detection of atrial natriuretic peptide receptor in the labyrinth of the mouse inner ear. Neuro Endocrinol Lett 29: 577-580, 2008.

10. Long L, Tang Y, Xia Q, Xia Z and Liu J: The expression of atrial natriuretic peptide receptor in the mouse inner ear labyrinth. Neuro Endocrinol Lett 31: 126-130, 2010.

11. Chen HX, Wang JL, Liu QC and Qiu JH: Distribution and location of immunoreactive atrial natriuretic peptides in cochlear stria vascularis of guinea pig. Chin Med J (Engl) 107: 53-56, 1994.

12. Loffing J and Schild L: Functional domains of the epithelial sodium channel. J Am Soc Nephrol 16: 3175-3181, 2005.

13. Garty $\mathrm{H}$ and Palmer LG: Epithelial sodium channels: function, structure, and regulation. Physiol Rev 77: 359-396, 1997.

14. Couloigner V, Fay M, Djelidi S, et al: Location and function of the epithelial Na channel in the cochlea. Am J Physiol Renal Physiol 280: F214-F222, 2001.

15. Yoon YJ and Hellstrom S: Immunohistochemical localization of alpha-atrial natriuretic polypeptide in the rat cochlea. Acta Otolaryngol 112: 604-610, 1992.

16. Higuchi R, Fockler C, Dollinger G and Watson R: Kinetic PCR analysis: real-time monitoring of DNA amplification reactions. Biotechnology (NY) 11: 1026-1030, 1993.

17. Marcus DC and Chiba T: $\mathrm{K}+$ and $\mathrm{Na}+$ absorption by outer sulcus epithelial cells. Hear Res 134: 48-56, 1999.

18. Takeuchi S, Ando M, Kozakura K, Saito H and Irimajiri A: Ion channels in basolateral membrane of marginal cells dissociated from gerbil stria vascularis. Hear Res 83: 89-100, 1995.

19. Bhalla V and Hallows KR: Mechanisms of ENaC regulation and clinical implications. J Am Soc Nephrol 19: 1845-1854, 2008.

20. Potter LR, Abbey-Hosch S and Dickey DM: Natriuretic peptides, their receptors, and cyclic guanosine monophosphate-dependent signaling functions. Endocr Rev 27: 47-72, 2006.

21. Fried TA, Osgood RW and Stein JH: Tubular site(s) of action of atrial natriuretic peptide in the rat. Am J Physiol 255: F313-F316, 1988.

22. Argenzio RA and Armstrong $\mathrm{M}$ : ANP inhibits $\mathrm{NaCl}$ absorption and elicits $\mathrm{Cl}$ secretion in porcine colon: evidence for cGMP and Ca mediation. Am J Physiol 265: R57-R65, 1993.

23. Waldman SA, Rapoport RM and Murad F: Atrial natriuretic factor selectively activates particulate guanylate cyclase and elevates cyclic GMP in rat tissues. J Biol Chem 259: 14332-14334, 1984.

24. Kiemer AK, Bildner N, Weber NC and Vollmar AM: Characterization of heme oxygenase 1 (heat shock protein 32) induction by atrial natriuretic peptide in human endothelial cells. Endocrinology 144: 802-812, 2003.

25. Pilz RB and Casteel DE: Regulation of gene expression by cyclic GMP. Circ Res 93: 1034-1046, 2003. 